\title{
Understanding Housing Management by Low-income Homeowners: Technical, Organisational and Sociocultural Challenges in Chilean Condominium Housing
}

\author{
Luz María Vergara * ${ }^{\circ}$, Vincent Gruis and Kees van der Flier \\ Department of Management in the Built Environment, Faculty of Architecture and the Built Environment, \\ Delft University of Technology, Julianalaan 134, 2628 BL Delft, The Netherlands; V.H.Gruis@tudelft.nl (V.G.); \\ C.L.vanderFlier@tudelft.nl (K.v.d.F.) \\ * Correspondence: L.M.VergaraDalencon@tudelft.nl
}

Received: 11 February 2019; Accepted: 5 March 2019; Published: 13 March 2019

check for updates

\begin{abstract}
In the context of social vulnerability, the house is an important social and economic resource to cope with poverty. However, low-income homeowners face constraints to maintain their houses, negatively affecting the quality of their dwellings, buildings and neighbourhoods. In the case of Chile, current studies have shown high levels of housing deterioration due to the lack of maintenance, but more knowledge is needed to understand the problems behind this poor management process. One important challenge is to consider an integral approach, beyond the technical dimension, that includes organisational and sociocultural inputs. Therefore, this paper presents the results of an exploratory study about the nature of the management problems in the context of Chilean low-income condominiums. The method considered semi-structured interviews with Chilean homeowners, researchers and professionals from the private sector, municipalities and central government. Main findings show the interdependencies between sociocultural, organisational and technical dimensions of the management problem; and the relevance of the sociocultural variables to perform technical maintenance activities. A better understanding of the nature and relationships among the management problems will provide better tools to improve current housing management models.
\end{abstract}

Keywords: condominium housing; low-income homeowners; maintenance; Chile

\section{Introduction}

In the context of vulnerability, the house is an important social and economic resource to cope with poverty. The house has been defined as a "productive asset" for urban poor households, which cushions them against severe poverty [1]. Following this, the house provides opportunities for income generation; homeowners develop strategies according to their needs such as home-based productive activities, resting rooms or give shelter to the extended family [1-3]. Furthermore, homeownership has been associated with intangible benefits derived from the property' rights such as security, freedom and independence.

One major challenge for low-income homeowners is to provide adequate maintenance to their homes in order to ensure that the housing value will increase over time and thus, to preserve the associated opportunities and benefits. The literature has described maintenance problems among the owner-occupied housing stock and the consequences in housing and neighbourhood deterioration. Several authors have mentioned the challenges for low-income homeowners to maintain and repair their dwellings in the long-term due to financial constraints [4-9]. Regarding condominiums 
and multi-owned buildings, scholars have mentioned organisational shortcomings due to unclear governance networks and norms to manage the communal parts [10-12]; and the lack of participation of individuals within a group in collective management, especially, when personal and collective interests are confronted [11,13]. Furthermore, authors have mentioned the role of public policies in supporting and assisting the housing management process, especially, when the governments have promoted ownership among low-income households [14,15].

The case of Chile is illustrative regarding the problems of low-income homeownership and the challenges of housing management. Chilean housing policies have promoted ownership among the poorest families during the last thirty years. As a result, the affordable housing stock and its neighbourhoods present high levels of deterioration and devaluation [16,17]. Medium-rise building apartments named social condominiums (Condominios Sociales) became the icon of the most problematic housing type in terms of low initial construction quality, the neglected maintenance of the common property, organisational shortcomings and social conflicts. The challenge of low-income homeownership in Chile is twofold. On the one hand, it includes the financial and social restrictions faced by homeowners that diminish their collective capacity to take care of building maintenance. On the other hand, it includes institutional limitations with regard to housing and condominium management in terms of regulations, institutions, and actors.

An extensive amount of studies describes Chilean socioeconomic, urban and architectural problems in houses and neighbourhoods as consequences of the housing policies [18-24]. On the contrary, the literature on the topic of housing maintenance and the understanding of housing management problems is scarce, especially regarding strategies to deal with the current housing stock. While main research contributions have focused on housing provision and how to improve its quality, more knowledge is needed regarding the problems underlying the poor management of the current housing stock.

Considering the context of social vulnerability, one important challenge is to understand the management problem beyond the building itself. This implies the need to develop more integral approaches that include other aspects of the problem such as cultural background, organisational process, family composition and collective action. Housing management for low-income homeowners can be understood as a multidimensional problem that considers social, technical and organisational variables in which homeowners play a leading role.

This paper aims to contribute to the field of housing management in the context of low-income homeownership. To do this, we carried out an exploratory study about the nature of the management problems in the context of Chilean low-income homeowners. The following questions are answered in this paper: (1) What are the characteristics of housing management for Chilean low-income homeowners in technical, organisational and sociocultural dimensions? (2) How are they related in the case of Chile? The method considers semi-structured interviews in the Chilean context with homeowners, researchers, and professionals. Main results show an important interdependence among the dimensions, as well as the relevance of sociocultural and organisational problems to trigger technical problems.

The paper is structured as follows. First, background about condominium management in the Chilean context. Second, the theoretical framework of housing management from a multidimensional perspective. Third, the results from the interviews carried out in Chile, including methods and approaches. Fourth, the analysis of interrelations between the defined housing management dimensions in the Chilean experience and considerations for future actions.

\section{Condominium Management in Chile: Regulations, Policies and Actors}

The concept of social condominium (condominio social) is used by the Chilean government to describe the housing typology comprised of medium-rise building apartments which contains areas of individual property and common domain property. 
Table 1. Maintenance problems and problematic uses in social condominiums.

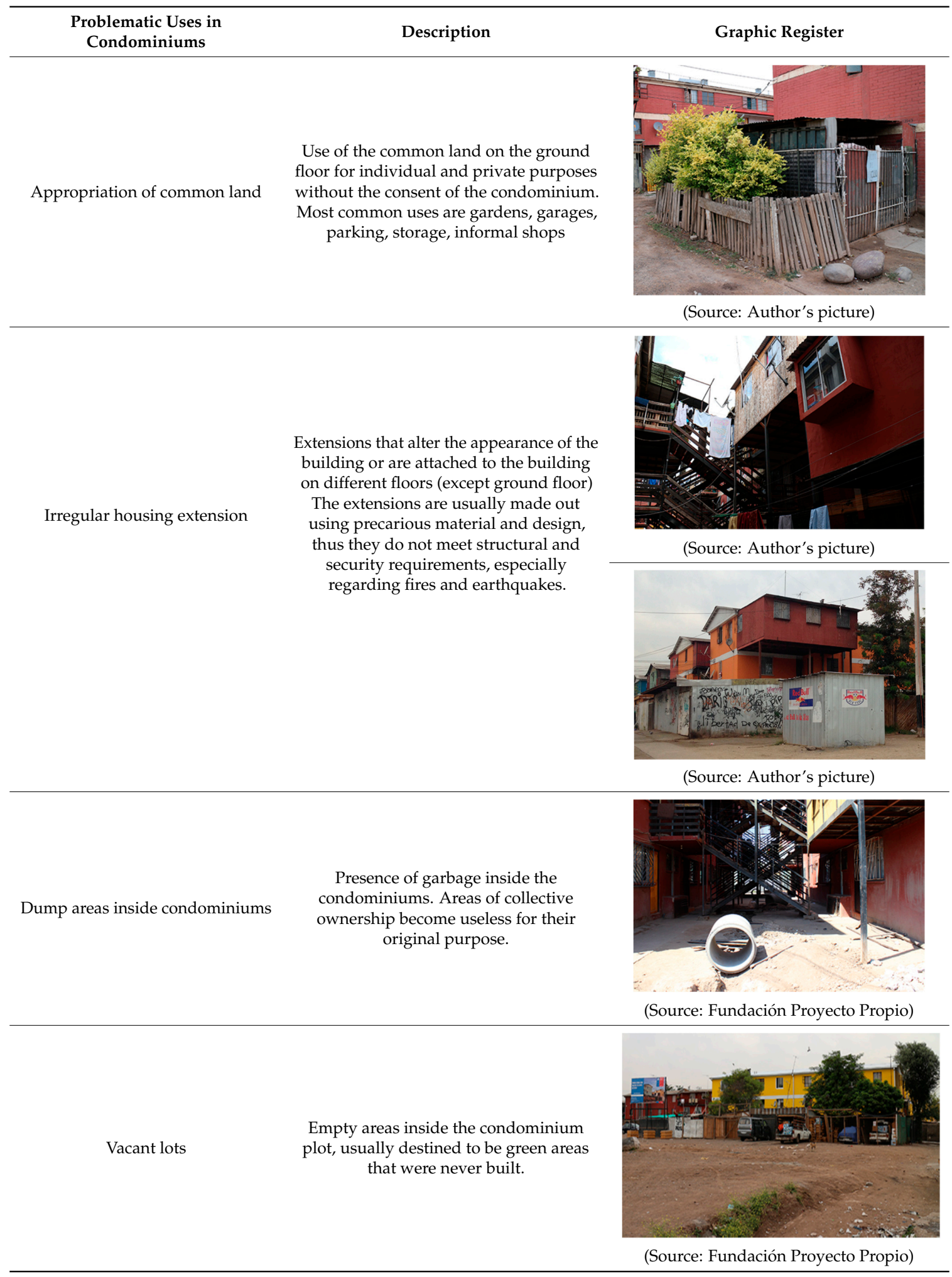

Between 1936 and 2013, the government subsidised the construction of 5689 social condominiums, comprising 344,000 dwellings. The metropolitan region of Santiago, the capital city, has $56 \%$ of these condominiums: 3186 condominiums and 194,808 dwellings [25]. A national cadastre conducted by the government showed that $99 \%$ of social condominiums present maintenance problems, with either regular $(30 \%)$ or bad $(69 \%)$ general maintenance indices, especially those built between 1980 and 
1999 [25]. As shown in Table 1, the main maintenance problems and problematic uses identified in common domain areas are the appropriation of common land (especially by ground floor apartments), irregular housing extensions, rubbish areas inside the condominiums and the existence of vacant lots.

The regulatory framework for condominiums is Law $\mathrm{N}^{\circ} 19.537$ from 1997, the Ley de Copropiedad Inmobiliaria (Co-ownership Law), which establishes administrative and behavioural guidelines for people who live in condominium tenure. This law defines the individual property (i.e., apartment or unit) and the common domain property (i.e., structure, façade, roof, elevators, staircases, courtyard, service rooms, parking lot) within a condominium. It also stipulates basic administrative regulations to ensure a healthy living environment. The co-ownership law addresses the following main organisational elements: Condominium administrative committee, administrator, co-owners assembly, condominium regulations and monthly expenses for maintenance. Condominiums voluntarily choose to organise themselves according to the law. In 2014, this law was modified, introducing one special chapter for social condominiums with the purpose of facilitating organisation among low-income owners. The result was less restrictive regulation in terms of quorums for co-owner assemblies and more flexibility to create the administrative committee and to assign the administrator [26].

A condominium that has been 'legalised' (registered as an organisation in the Real Estate Register (CBR) obtains a juridical personality and is, therefore, more visible and able to access municipal support or benefits, given its status as an organisation. There are no regulatory frameworks related to maintenance practices, however, or the definition of maintenance parameters that owners need to achieve. Additionally, neither the central government nor municipalities have legal rights or the capacity to force the implementation of maintenance practices or implementation of the co-ownership law in condominiums.

Administration services for condominium management are commonly provided by private (for profit) enterprises, but they do not work with low-income groups. Besides some municipal assistance, the main access to institutional support for low-income homeowners is the subsidy programme for social condominium improvements (PMCS) which focuses on improving the physical quality of highly deteriorated condominiums. To apply to the subsidy, the co-owners must liaise with an assistance entity (PSAT), which are private organisations (profit or not profit) or municipal departments entitled to carry out subsidy programmes. These programmes carry out technical improvements in the common property and support the co-owners to legalise their condominium. The subsidy contributes to improving the aesthetical and security conditions of deteriorated condominiums, however, it does not provide support for long-term administration and maintenance, moreover, its implementation alone does not ensure the sustainability of the improvements over time.

\section{Multidimensional Framework for Condominium Management}

Housing management is defined as " $=$ " 'the set of all activities to produce and allocate housing services from the existing housing stock' [27], and has been widely discussed in the social housing field; especially, regarding the role of housing associations in the management of affordable European housing stock [27-30]. One of the main goals is to ensure adequate maintenance by conducting 'technical and associated administrative actions during the service life to retain a building or its parts in a state in which it can perform its required functions' [31]. In this regard, housing management implies forward planning and the use of professional skills to execute activities at the right time.

Conversely, a smaller part of the literature has focused on the management of the owner-occupied sector, particularly when the property is collectively owned [32]. General aspects of social housing management, related to the physical conditions of dwellings and the organisation of technical tasks, may also apply to the owner-occupied sector; however, there are major differences in who is leading the process. In the owner-occupied sector, responsibility is on homeowners, which strongly ties the decisions about management to the financial, cultural and individual situation of households, creating social and financial connections between co-owners [11]. This situation entails complex arrangements for collective decision making to take care of the common property areas which are more subject to 
deterioration [33]. When discussing condominium tenure management, scholars have referred to the tension between the individual and the group which affects decision-making actions, and, therefore, the efficacy of the management of the collective good [11,13]. In this regard, the existence of social norms and a sense of community have been noticed as relevant in shaping collective behaviour and fostering individual participation, and therefore, in achieving better management [12,34]. In order to have a broad understanding of condominium management, three approaches are reviewed, based on organisational management theory, collective action theory, and a social vulnerability framework.

In the context of privatised housing stock and according to organisational management theory, Gruis, Tsenkova [6] developed a framework to analyse and compare housing management characteristics in relation to housing quality among Western and Eastern European countries, Australia, and China. The selected cases had experimented with significant rates of privatisation of their social housing stock since 1990, especially in multi-owned buildings. They identified seven elements of housing management; policy/strategy, financial resources, human resources, culture, organisational structure, legal framework and housing quality [6]. In this framework, the main goal of housing management is to maintain the quality of housing, which is the result of interrelated outcomes among the elements. The comparative analysis demonstrated that 'in different cultural settings, similar processes and policy interventions can have quite different outcomes and implications in the area of housing management' [6]. The framework includes elements of management related to the institutional and cultural background, which contribute to the understanding of housing management and housing quality in light of the specific context.

A second approach to ownership and housing management is developed from the collective action theory [35]. The condominium is seen as a common pool or common property resource (CPR) that faces challenges in its collective management [36]. From this perspective, several authors have focused on governance problems, using the collective action dilemma to explain and to understand the individual behaviour within a group; such as the cost/benefits of participating in management activities, the contrast between individual and collective expectations about the management, and the existence of free-riders that benefit from the group [11,33,37-40]. In this context, the Institutional Analysis and Development Framework of Ostrom [41] has been applied by different authors $[33,40]$ to explain exogenous factors that might affect the decision-making process of maintenance activities, such as the attributes of the owner group, the proper delineation of property rights, and adequate physical conditions to be maintained. This framework combines three different institutional characteristics involved in common property management: The communities, governance, and the physical environment.

Another factor in the definition of housing management for the affordable owner-occupied sector can be found in the asset vulnerability framework [1]. Although this framework is not directly related to housing management, it provides insights into the dynamics of low-income owners and its impact on housing management activities. Moser focuses on household perspectives, highlighting the opportunities and the strategies derived from the management of their assets. The framework emphasises the importance of the house as a productive asset in which homeowners, in the context of vulnerability, develop strategies for income generation such as building and renting rooms, developing home-based productive activities or giving shelter to the extended family. These actions are also related to intangible acts, such as household relationships and social capital.

These family dynamics which often arise from informality do not often fit within formal institutions like condominiums. A common example in the Latin American context is the problem faced by families from informal settlements when they move to new housing complexes [42-44]. They tend to reproduce the same cultural and design patterns of informality in the new condominiums [44], which are usually rigid organisational structures with small dwellings and little potential for adaptation. Another example is when the families' strategies to improve their living conditions become a priority, neglecting or postponing actions beyond the family core. In some cases, when the group heterogeneity is considerable, the differences between owners (e.g., age, length of living, knowledge, residential 
trajectories) make the decision-making process even more complex and can negatively affect the management [45]. The aforementioned situations might lead to social conflicts inside condominiums, especially when they clash with the decisions and requirements of the group. Therefore, important challenges are involved in the use of common property and its effect on the sense of community [34], which has been defined as a relevant factor in collective property management.

The previous definitions related to housing management provided different approaches to understanding the concept. Although the frameworks emphasise different aspects of management, considering either internal (directly related to internal management inside the condominium) or external variables (related to the context where the management is carried out), all refer to at least one of these three main areas: The physical domain, related to housing quality; the organisational domain, related to the governance and coordination of resources; or the social domain, related to the characteristics and behaviour of the community who live in these condominiums. Therefore, a comprehensive framework for housing management in the affordable owner-occupied sector considers the following characteristics:

- The management is a multidimensional process which goes beyond technical features, involving sociocultural and organisational dimensions. The final outcome is to achieve quality in the built environment and to guarantee the value of the house as an asset for vulnerable groups.

- The main actors of the process are the households, with their own socioeconomic and cultural dynamics. The decisions related to the built environment are part of the private domain and are voluntary in nature.

- There are internal and contextual elements that might positively or negatively affect management practices. Internal elements are related to the dynamics inside the condominium and depend on the co-owners as individuals and as a community, and contextual elements are related to the context conditions and depend on the institutional sphere and its policies.

Housing management for privately-owned affordable condominiums can be defined as a multidimensional process to ensure the proper functioning of the condominium considering three interrelated dimensions: Technical, organisational and sociocultural. Contextual elements are also considered in relation to property law, institutions and policies since they impact the overall management of the condominiums. The condominium is understood as a common property resource, collectively managed by co-owners with the purpose of maintaining the quality of the built environment. Figure 1 shows these dimensions and the respective elements and Table 2 describes them.

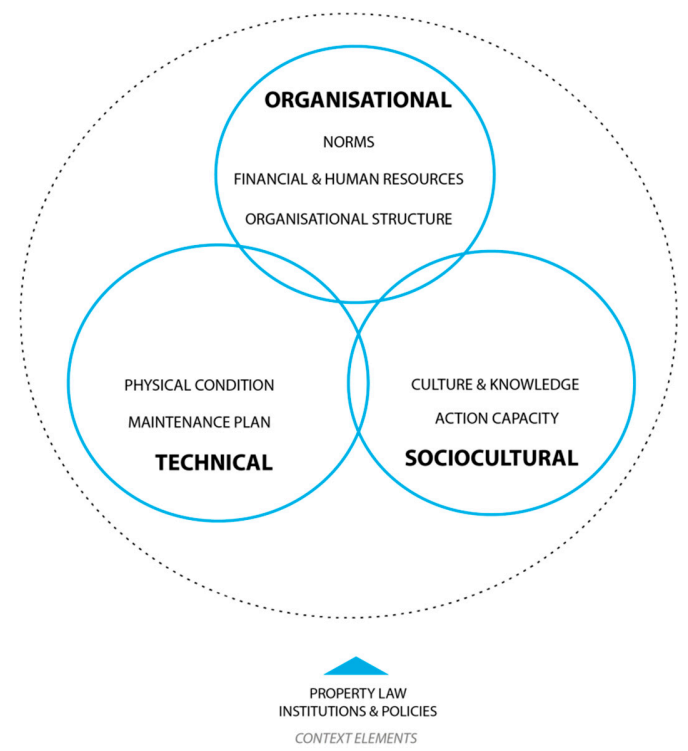

Figure 1. Housing management dimensions and elements. Source: author's image. 
The technical dimension refers directly to the built environment, considering the characteristics of the constructed facilities and the physical performance of the building in terms of comfort, security, design and aesthetic conditions. In condominiums, this involves activities to maintain not only the dwellings but also the common domain areas, such as the structure, façade, roof and shared facilities (corridors, elevator, staircases, meeting rooms, heating/cooling systems etc.)

Table 2. Condominium management dimensions and elements.

\begin{tabular}{|c|c|c|}
\hline Dimension & Elements & Description \\
\hline Technical & Physical conditions & $\begin{array}{l}\text { Characteristics of the building regarding its structure, thermal comfort, } \\
\text { security, design and aesthetic appearance. }\end{array}$ \\
\hline \multirow[t]{3}{*}{$\begin{array}{l}\text { Organisational } \\
\text { Sociocultural }\end{array}$} & $\begin{array}{l}\text { Financial and human } \\
\text { resources }\end{array}$ & $\begin{array}{l}\text { Internal or external resources needed for the management. } \\
\text { - Financial resources: Financial capacity to carry out maintenance } \\
\text { activities. The resources are divided into two types according to } \\
\text { activities: Resources for short-term maintenance or routine } \\
\text { maintenance, and resources for long-term maintenance, which in } \\
\text { collective buildings are part of a maintenance fund. It is also possible to } \\
\text { identify internal financial resources that come from the owners' } \\
\text { financial capacity and external financial resources that come from } \\
\text { government subsidies, affordable loans or other private contributions. } \\
\text { - Human resources: Co-owners and professionals are required to } \\
\text { perform and coordinate the administrative and technical activities. } \\
\text { Human resources can be either internal or external. Internal human } \\
\text { resources are the individuals who belong to the condominiums (for } \\
\text { instance, members of the condominium board, volunteer } \\
\text { administrators) and external human resources are professionals or } \\
\text { organisations hired by the co-owners (for instance, contractors to } \\
\text { perform technical maintenance, property managers or agencies). }\end{array}$ \\
\hline & Organisational structure & $\begin{array}{l}\text { Umbrella institution or group where the activities are carried out. In the } \\
\text { case of condominiums, the formal structure is the assembly of } \\
\text { co-owners, named in some contexts as the homeowner association. It } \\
\text { also includes alternative organisational structures that contribute to the } \\
\text { internal governance. }\end{array}$ \\
\hline & Action capacity & $\begin{array}{c}\text { The willingness and capacity of co-owners to carry out the management } \\
\text { activities. In condominiums, this capacity will depend on the collective } \\
\text { action of the group working together to achieve the objective of housing } \\
\text { management, and the presence of elements such as social capital and } \\
\text { trust in the leaders. }\end{array}$ \\
\hline \multirow{2}{*}{ Contextual elements } & Property law & $\begin{array}{l}\text { Formal legal framework that regulates condominium tenure and } \\
\text { defines property rights and obligations. }\end{array}$ \\
\hline & Institutions and policies & $\begin{array}{l}\text { Private or public institutions that participate in condominium } \\
\text { management practices at an external governance level. It also comprises } \\
\text { the policies that impact the management of the condominiums }\end{array}$ \\
\hline
\end{tabular}

The organisational dimension refers to the coordination of the human and financial resources required to conduct the technical and administrative activities under the specific internal rules and governance structure embedded in an institutional and legal framework. In condominiums, the decisions are taken by the group of co-owners organised as a homeowner association. In most cases, a board of co-owners coordinates the human and financial resources related to the common domain areas.

The sociocultural dimension refers to the behaviour of the co-owners as individuals and as a group, with respect to their built environment. This implies a cultural perception and knowledge of 
maintenance and the willingness to carry out such activities. In condominiums, the actions are driven by group benefits and also by individual interests. This dimension is related to the socioeconomic and educational characteristics of the residents but also to the social capital and the cohesion of the community as a group.

This multidimensional framework is intended to describe the characteristics of housing management for low-income groups and to identify the main problems and challenges. It also allows the main relationships to be identified between the dimensions and the elements according to the local characteristics of the community and the institutions.

\section{Materials and Methods}

The housing management framework presented was used to analyse the case of Chile and to understand how the management processes are perceived by key stakeholders in the Chilean context, namely central government, assistance entities, researchers, and residents, and to identify the main challenges for Chilean low-income homeowners with respect to condominium management practices. The main sources for the analysis were interviews performed in Chile. The goal was to obtain empirical information about housing management problems and challenges from the point of view of professionals and homeowners.

The fieldwork consisted of two parts carried out in February 2015 and January 2016, respectively. The first part consisted of interviews with professionals from the public, private and third sector involved in housing management activities. These interviews presented the first approach to housing management problems. The second part consisted of interviews with homeowners in order to contrast the external perception with the experience of homeowners regarding the management of their homes. A qualitative analysis was conducted to analyse the responses using both inductive and deductive approaches. The interviews were transcribed and then analysed with the atlas.ti software to code and retrieve the data, organising it by thematic labels. The topics addressed by the interviewees were then related to the proposed framework.

\subsection{Interviews with Professionals}

The first group of interviewees included professionals from Chilean public institutions, researchers and assistance entities (PSAT). The data collection methods consisted of face-to-face and structured interviews. In total, fifteen interviews were performed with three professionals from academia, four professionals from the Ministry of Housing and Urbanism (MINVU) and Housing and Urbanisation Services (SERVIU), and six assistance entities (PSAT), including for-profit, non-profit and municipalities. Professionals were selected according to their experience in housing maintenance and subsidy programmes related to the improvement of housing and social condominiums. The sample allowed for coverage of a broad spectrum of professional participation in condominium management activities either in the design of policy, the supervision of its implementation, the implementation itself, or in research about the topic

As shown in Table 3, the interview form consisted of six questions. Questions one to four focused on the issues and problems of each management dimension. The fifth question was about their hierarchical order, and the last question was about the main opportunities and threats of future courses of action to improve housing maintenance practices. 
Table 3. Questionnaire individual interviews with housing professionals.

\begin{tabular}{cc}
\hline$\#$ & Questionnaire \\
\hline Q\#1 & What, in your opinion, are the main technical problems/issues of housing management* in Chile? \\
Q\#2 & What in your opinion, are the main organisational problems/issues of housing management* in Chile? \\
Q\#3 & What, in your opinion, are the main social/cultural problems of housing management* in Chile? \\
Q\#4 & Do you think that there are other types of problems/issues which are not considered in the previous \\
Q\#5 & categories? What are they? \\
Q\#6 & What should be, in your opinion, the course of action to improve housing maintenance in Chile? What \\
& are the opportunities and threats?
\end{tabular}

The questions were formulated in Spanish using the concept of housing maintenance and administration (mantenimiento y administración) instead of management. In Chile, housing management (gestión de la vivienda) is an emergent field and, therefore, the concept is not commonly used by stakeholders to refer to the upkeep and administration of the housing stock.

\subsection{Interviews with Condominium Residents}

The second part of the fieldwork consisted of a group interview with nine residents from seven different social condominiums built between 1976 and 1990. All selected condominiums were from the same municipality (Lo Prado) in order to understand management problems under the same background conditions. Lo Prado is representative of a low-income district with a high percentage of social condominiums compared to the total housing stock of the municipality (30\%) [25]. The use of a group interview seemed to be appropriate in order to obtain feedback from different condominiums simultaneously while obtaining insights based on the group interaction in a controlled discussion environment [46]. The group interview was performed in the Housing Department of the municipality after working hours, providing the physical facilities without the municipal staff that might affect the group interaction. In order to ensure a safe environment, the anonymity of the participants was guaranteed.

Participants were selected according to two main criteria. First, they had to be residents and homeowners in social condominiums recently improved by the Programme of Improvement of Social Condominiums (PMCS). This facilitates information about management problems and challenges before and after the governmental intervention. Second, the participants were also part of their respective administrative committees. The decision to invite only condominium representatives was two-fold. They are more informed about the problems in their condominium and they are also more willing to cooperate in this type of activity.

The interview consisted of five questions displayed in Table 4. The first two questions were about the understanding of maintenance, identifying the main activities carried out by the residents. Questions three and four focused on the identification of the main management problems and challenges before and after the intervention in the condominium. The last question referred to the lessons acquired during the improvement process.

The deterioration of common spaces in co-property was mentioned as a critical issue, considering the consequences at the neighbourhood level. It was reported that owners take care of each apartment, but nobody is taking care of the common property areas. Professionals from central government, PSATs and researchers mentioned the initial low-quality of social condominiums in terms of construction, location and design and how these problems also impact maintenance activities.

'[The technical problem is] the quality of the existing housing stock, its bad location and the tools to take over maintenance problems are not enough. Housing deterioration contributes to the devaluation of the heritage and [generates] impoverishment' (interview, non-profit PSAT, March, 2015).

Housing extensions were perceived by researchers, central government and PSATs as major problems since they create a risk of collapse due to their precarious conditions. While the informality of the extensions was associated with the complexity of the municipal approval processes, the 
precariousness was associated with financial constraints and the prevalence of do-it-yourself solutions without professional guidance.

'The main problems are the extensions in terms of safety and legality. In theory, the owner would invest in their house. The problem is that they do not know the technical norms. The [new] model of social housing has been made incrementally, but society does not have the technical tools to do this properly'(interview, municipal PSAT, March, 2015).

Another point mentioned by for-profit PSATs was the limitations of the budget for subsidies for repairs and extensions, which restricts the quality of solutions, to address the needs of families and to incorporate innovation in design. One of the profit PSATs mentioned that 'the system offers incentives to implement the easiest solutions, which are cheap and standard solutions'.

In the organisational dimension, participants from academia, central government and PSATs raised the question of who should be responsible for the maintenance of the housing stock and to what extent it is a homeowner or central government task. Some considered it a homeowner responsibility due to it being private property. Others argued that it is a government debt to the families, due to the initial low quality of the design of social condominiums, especially regarding responsibility for common spaces in condominium tenure. They also pointed out the limited financial capacity of homeowners to invest in maintenance and the lack of policies focused on maintenance.

PSATs perceived that homeowners do not trust the system or the organisations. It was indicated that 'the majority of social condominiums are not legalised according to the co-ownership law. To be a formal condominium is not perceived as a positive feature by homeowners and tenants' (interviews, non-profit PSAT, March 2015). Non-profit organisations and researchers reported that homeowners and communities are passive actors in the subsidy system, which is also reflected in the decrease of collective organisation. One current important challenge mentioned is 'to strengthen internal organisations and the management of condominiums' (Interview, MINVU professional, March 2015).

Most of the answers were related to contextual variables, however, and specifically, the process of the subsidy for improvements rather than internal organisational problems in condominiums. Researchers and central government professionals mentioned the need for mechanisms to assess the results of the subsidy in terms of the sustainability of the programmes and success of the interventions over time.

For some PSATs and researchers, the subsidy process is complex, especially in administrative paperwork. PSATs also noted that this complexity has discouraged families from applying. They made positive remarks regarding the transparency of qualification criteria, however, and the results of short-term interventions. Another issue reported was the shortcomings of the allocation of financial resources and the limited offer of builders to work on small-scale projects.

The sociocultural dimension of housing management was recognised as a relevant dimension, especially its relationship with technical and organisational problems. The first topic mentioned was the importance of awareness and education about housing maintenance and about living in a condominium. There is a general perception among interviewees that housing maintenance is not fully incorporated into cultural behaviour. The lack of education about maintenance activities was mentioned as a major concern, and even more important than financial problems. This knowledge gap is also related to co-property, where the lack of knowledge about duties has led to problems regarding the use of the common and public spaces. The appropriation of common ground was associated with the need to increase security but also to power-related issues. Participants perceive individualism among homeowners when they have to pursue common goals.

'There is a lack of knowledge about how to live in these dwellings, there is an educational vulnerability rather than financial. Some families continue living in the same way [making reference to relocated families from slums] even though they have a new house or they have improved their houses $(. .$.$) the main goal for us is to address family awareness about the importance of housing$ maintenance' (interview, municipal PSAT, March 2015) 
'The main reason for the most deteriorated houses is the lack of education and awareness about housing maintenance, rather than financial problems' (interview, profit PSAT, March 2015)

'People do not understand the difference between individual property and common property ( . . ) they feel insecure and erect a fence, and close common property areas' (interview, profit PSAT, March 2015)

Despite the lack of specific knowledge about maintenance, it was also argued by a non-profit PSAT that families nowadays have better financial situations in general than previous generations, as well as greater access to higher education opportunities. Nevertheless, this is a generation of homeowners still unknown by the government.

Another important topic for all participants was family priorities and allegamiento (give shelter to the extended family in the same dwelling or plot). They explained that maintenance activities and the quality of extensions have been displaced by structural family problems. They argued that peoples' priorities are related to obtaining more floor space for their extended family, improving their security in hostile environments and to acquiring goods. It was also noted that 'extensions are built from the first day families start living in the new houses, and they reproduce the same living conditions as in the slums' (interview, SERVIU professional, March 2016). It was emphasised that the allegamiento in itself is not the problem, the problem is how the families build the extensions on the site.

Municipal PSAT and SERVIU professionals pointed out that the housing policy based on subsidies has generated a lack of commitment by homeowners to take care of their projects after completion. Finally, researchers and PSATs pointed out the impact of neighbourhood deterioration on families' mental wellbeing, especially regarding the initial low-quality of the housing stock.

Table 4. Questionnaire group interview with condominium residents.

\begin{tabular}{cc}
\hline$\#$ & Questionnaire \\
\hline Q\#1 & When we talk about housing maintenance, which activities come to your mind? \\
Q\#2 & How do you maintain your dwellings, which activities do you do regularly and occasionally? \\
Q\#3 & What were the main management problems* before the improvement of the condominium? \\
Q\#4 & What are the main management problems* now, after the improvement of the condominium? \\
Q\#5 & What did you learn from the improvement process? \\
\hline The questions were formulated in Spanish using the concept of housing maintenance and administration \\
(mantenimiento y administración) instead of management. In Chile, housing management (gestión de la vivienda) \\
is an emergent field and, therefore, the concept is not commonly used by stakeholders to refer to the upkeep and \\
administration of the housing stock.
\end{tabular}

\section{Results}

\subsection{Perception of Management Dimensions and Challenges among Chilean Institutions, Researchers and Asistance Entities}

Following the questionnaire, the responses were organised into two main parts. The first was the management problems identified for each dimension. The second was the course of action to improve maintenance practices in the future.

Table 5 summarises the main issues and problems associated with the technical dimensions of housing management. One of the main concerns mentioned is the general deterioration of the housing stock. There was a consensus about the lack of housing maintenance activities and this was further related to a lack of education and knowledge among homeowners about the benefits of maintaining their dwellings, a problem that is present at all socioeconomic levels. They also mentioned specific architectural and constructive problems that commonly affect buildings and houses, such as the presence of toxic material in roofs, poor thermal insulation, problems in building services, lack of ventilation and light, and the structural instability of extensions. 
Table 5. Categorisation of housing management problems mentioned by housing professionals (from Chilean public institutions, researchers and assistance entities (PSAT) according to dimensions and elements.

\begin{tabular}{|c|c|c|}
\hline \# & Management Problems Noted by Stakeholders & Elements Addressed \\
\hline \multicolumn{3}{|c|}{ Technical dimension of condominium management } \\
\hline 1 & Need to differentiate between extensions, improvement and maintenance & Maintenance plan \\
\hline 2 & General physical deterioration due to the lack of maintenance & $\begin{array}{l}\text { Maintenance plan } \\
\text { Physical condition }\end{array}$ \\
\hline 3 & Deterioration of common property areas in condominiums & Physical condition \\
\hline 4 & $\begin{array}{l}\text { Informality and precariousness of housing extensions and safety risks } \\
\text { associated with them }\end{array}$ & Physical condition \\
\hline 5 & $\begin{array}{l}\text { Lack of quality in solutions implemented due to the lack of financial } \\
\text { resources (subsidy and DIY) }\end{array}$ & Physical condition \\
\hline 6 & Initial low-quality conditions of the housing stock & Context-institutions and policies \\
\hline 7 & $\begin{array}{l}\text { Specific architectural and constructive problems (toxic material in roofs, } \\
\text { poor thermal isolation, lack of ventilation) }\end{array}$ & Physical condition \\
\hline \multicolumn{3}{|c|}{ Organisational dimension of condominium management } \\
\hline 1 & Unclear responsibilities in housing maintenance & Context-institutions \\
\hline 2 & Community does not trust in the system and its institutions & $\begin{array}{c}\text { Norms } \\
\text { Context-property law and institutions }\end{array}$ \\
\hline 3 & Limited financial capacity of homeowners to invest in maintenance & Financial resources \\
\hline 4 & Assistance entities and the externalisation of the work (subsidy process) & Context-institutions \\
\hline 5 & $\begin{array}{c}\text { Shortcomings in the implementation of the subsidy programmes for } \\
\text { improvements (subsidy process) }\end{array}$ & Context-institutions \\
\hline 6 & Passive homeowners and decrease of collective organisation & Organisational structure \\
\hline 7 & Sustainability and success of the interventions (subsidy process) & Context-institutions \\
\hline 8 & Inexistence of policies about maintenance & Context-institutions and policies \\
\hline \multicolumn{3}{|c|}{ Sociocultural dimension of condominium management } \\
\hline 1 & Lack of awareness and education about housing maintenance & Culture and knowledge \\
\hline 2 & $\begin{array}{l}\text { Problems of community organisation and individualism among } \\
\text { households }\end{array}$ & Action capacity \\
\hline 3 & Lack of knowledge about the co-property law & $\begin{array}{l}\text { Culture and knowledge } \\
\text { Norms }\end{array}$ \\
\hline 4 & $\begin{array}{l}\text { Reproduction of behaviour patterns of informal settlements in new } \\
\text { houses }\end{array}$ & Culture and knowledge \\
\hline 5 & $\begin{array}{l}\text { Lack of commitment of families to take care of the projects after } \\
\text { completion (subsidy process) }\end{array}$ & Action capacity \\
\hline 6 & Families priorities and allegamiento & Culture and knowledge \\
\hline 7 & New type of society and poverty & Action capacity \\
\hline 8 & Quality of neighbourhoods and buildings impacts on mental wellbeing & Action capacity \\
\hline
\end{tabular}

The three dimensions of housing management were recognised as relevant by the external stakeholders and understood as strongly related variables; however, when providing a hierarchical order, answers from the central government and PSATs emphasised the importance of sociocultural dimensions considering its effect on the other dimensions. In the case of the central government, current priorities are focused on increasing family participation in the subsidy programme and community empowerment in social condominiums. PSATs referred to homeowner education and the strengthening of community organisations as their main concerns.

The last questions were about opportunities and threats in the future of housing management. The responses showed a broad spectrum when it comes to opportunities. There are responses related to specific initiatives to reinforce community organisation and to educate homeowners, such as developing training programmes for the community and management networks for social condominiums. Another opportunity has been detected in the role of municipalities in managing the territory and giving support to families for maintenance activities. 
Opportunities regarding the implementation of a rental system and the improvement of housing quality in new houses were mentioned when discussing the housing policy system, in order to facilitate maintenance activities and to reduce deterioration problems in the future.

The experts noted the lack of productivity and commitment from government employees as threats to improving the current system. There is also a lack of trust in the system from community organisations and the big challenge of changing people's behaviour. The focus on excessive profitability by the private sector and the inadequate management of community participation in the subsidy programme were also considered as threats.

The consensus among the interviewees over some topics allows some key problems of cross-party concern to be identified in the current context, indicated in grey in Table 4. Researchers, central government and PSATs agreed about the existence of a deterioration pattern in the housing stock, especially affecting the condition of common spaces in social condominiums, as well as the risk associated with informal extensions. There is consensus on the sociocultural issues about the lack of awareness and education regarding housing maintenance activities among homeowners, the presence of allegamiento and other family priorities which affect maintenance activities and the difficulties of community organisation in condominium tenure. There is consensus over the lack of clarity of the duties and responsibilities of the management of the current housing stock.

\subsection{Perception of Management Dimensions and Challenges among Condominium Residents}

The participant's answers were organised into three main topics: First, the discussion about the main maintenance activities commonly practised in their condominium, secondly the identification of management problems, before and after the intervention, and thirdly, the experience and lessons from the implementation of the improvement in the condominium. The management problems were organised according to the different dimensions, see Table 6. It is worth mentioning that six out of nine participants were women. The prevalence of women leading voluntary organisations is representative of housing committees and neighbourhood associations.

Participants were asked about common maintenance practices. Some of the answers noted activities such as the improvement of their own houses, sweeping common areas, or watering gardens, but these are individual and spontaneous initiatives. There were no references to a maintenance plan or permanent coordinated actions. The only example of collective activities was fundraising for specific situations such as a funeral to economically support a family, to perform urgent minor repairs at the block level (one building) or to apply for the subsidy programme. 'To collect the money [to apply for the subsidy] we started to organise lunches, hold raffles, completadas [popular name for the activity to prepare and sell sandwiches] ... so the neighbours [were] well organised, we sold everything and we collected the money to apply' (Resident A).

In all the cases, the improvement carried out under the programme of social condominiums PMSC was the first project to improve the common property domain since the condominium was built, which in some cases was 38 years ago. One of the participants mentioned that 'maintenance was, in general individual, or there was some agreement between neighbours on a block where they defined what to do and then some funds were collected to improve things, but they were minor repairs (Resident A). It was noted that the participants talked in the past tense when they mentioned maintenance activities or the lack of them. While this shows that the improvement project has had an important impact on the condominium, it does not yet show any sign of a change of behaviour regarding maintenance practices'.

Participants noted a generalised and critical physical deterioration of the condominium as the main management problem before the intervention. They noted technical problems such as deteriorated roofs, the presence of contaminant materials (asbestos), collapse of rain gutters, presence of plagues of animals, structural damage due to earthquakes (especially in staircases), common courtyards converted into rubbish areas and emergency exits blocked by informal extensions. 'We had everything [referring to technical problems], from plagues of pigeons, street dogs, to leaking roofs 
( ... ) there were a lot of people who had a roof leaking, and I didn't know that some neighbours had a hole in the roof' (Resident A). Another problem noted was the lack of knowledge about the co-property law and the use of the common domain areas. Some participants reported that they did not know that some areas of the condominium were collective, or if they knew it, they did not have the tools and information about how to proceed in the case of illegal appropriation of common ground. They also noted the individualism among the residents and the lack of interaction between neighbours. Despite the lack of awareness of the co-property law and the low interaction, some noted informal arrangements between neighbours in the case of extensions on upper floors or the use of common areas as parking places; however, they were usually two-sided agreements between two neighbours, which did not involve the whole community.

A recurring element during the conversation was the fact of it being a copropiedad (condominium) and the benefits associated with it. Participants constantly noted the situation 'before we became a condominium', or 'before all of this arrived' or even 'the co-property movement' indicating the importance of the legalisation of the condominium as a new starting point to set up rules and to improve the quality of life.

'... because all this movement of co-property has emerged as social change when we became a condominium, because everything started all over again ... we started with an important project of fences, an important improvement to the dwellings, roof replacement, new lighting, everything because of that $(\ldots)$ before the co-property was established the people were indifferent because you live in your own square meter and you are not interested in what happens beyond that $(\ldots)$ when we became a co-property the rules started as well, because you have to change people's minds, everybody wants to live better, safer, cleaner and decent.' (Resident A, group interview, January 2016)

One of the most commonly noted current management problems is the appropriation of common areas on the ground floor and the side-effects in terms of safety and coexistence. Participants noted that residents on the ground floor take advantage of their situation, obtaining extra floor space, making profits from renting parking areas that belong to the whole condominium or converting these appropriations into rubbish areas. 'In our building we had an exit, but a neighbour added a room, and now she has converted it in a shop, and she closed the exit (Resident D); the people are appropriating and fencing off the ground floor, so is difficult to get out in case of emergency (Resident B); I think the people on upper floors have too much empathy with the people on the ground floor, their courtyards are usually full of garbage' (Resident A); however, some residents pointed out that the extensions on upper floors are made because they need space for basic activities.

Participants associated the misuse of common property with knowledge and behavioural problems among the residents. Knowledge problems are related to a lack of awareness about the use of the common property, as well as a reluctance to become formal condominiums. The upgrading of the condominium to legal status is related to assuming further financial responsibilities. 'It has been very hard to talk to the people about it [the co-property law] especially those who are afraid of the law, because of the garbage collection taxes or the monthly expenses' (Resident D); we are poor people, but also poor of knowledge' (Resident A). Some argued that, in addition to knowledge, the attitudes of the residents who take advantage for their own benefit or do not want to make collective efforts like keeping the common areas clean, take care of the gardens or cooperate on new projects are also a problem. 'We all like to receive benefits, but no one wants to strive to have them or be proactive on the topic, they just want to wait for them to arrive (Resident H); When I'm watering the garden some people have asked me how much I get paid for doing it, I reply that I do it because I want to ( ... ) or people of the second floor do not keep the access clean because it is not on their floor' (Resident $C$, group interview, January 2016)

Participation was also noted as something necessary, especially because the people who do not participate are the ones that complain the most. The residents noted that changing people's minds is too complicated. 'People do not participate in the meetings because they do not want to overcomplicate their lives, they don't care, they live in their own space (Resident B); I feel ashamed when the people 
afterwards forget about these things (the improvements) because generally, the people who do not participate are the people who complain, they have all the problems and do not trust anyone'. (Resident A).

The residents, as members of the administrative committees, also referred to problems related to trust in the administration of financial resources. Most of the participants pointed out the difficulties of collecting the money to apply for the subsidy or for the monthly expenses. They also have to convince the residents of the good use of the money, which is mostly to have a collective fund in case of emergencies. One of the most recurrent concerns of the residents is that the committee will use the money for personal purposes. In some cases, they have implemented internal mechanisms of supervision and reporting to prevent misunderstandings. Another issue was the workload and the pressure on the committee. They feel taken for granted by the residents, who often forget that their work is voluntary. 'The people think that it is our duty to do this, some of them say: you got involved in this, you have to know how to do it ( ... ) the people put pressure on you' (Resident C); 'and if something does not work out, we are responsible' (Resident D). The other problem that was discussed was the difficulty of organising big condominiums, especially when the governance overlaps with neighbourhood associations, creating conflicts between the organisational bodies.

Table 6. Categorisation of management problems reported by the residents according to dimensions and elements.

\begin{tabular}{|c|c|c|}
\hline \# & Management Problems Noted by Residents & Elements Addressed \\
\hline \multicolumn{3}{|c|}{ Technical dimension of condominium management } \\
\hline 1 & $\begin{array}{l}\text { Appropriation of common property on the ground floor blocking } \\
\text { emergency exits }\end{array}$ & Physical conditions \\
\hline 2 & General critical physical deterioration & Maintenance plan \\
\hline 3 & $\begin{array}{c}\text { Specific architectural problems (deteriorated roofs, presence of contaminant } \\
\text { materials (asbestos), collapse of rain gutters, structural damage due to } \\
\text { earthquakes) }\end{array}$ & Physical conditions \\
\hline 4 & Existence of plagues of animals and insects & Physical conditions \\
\hline 5 & Courtyards converted into rubbish areas & Maintenance plan \\
\hline 6 & Initial low-quality—need for space and extensions on upper floors & Context-institutions and policies \\
\hline \multicolumn{3}{|c|}{ Organisational dimension of condominium management } \\
\hline 1 & Reluctance to pay monthly expenses & Financial resources \\
\hline 2 & Workload for committee members & Human resources \\
\hline 3 & Residents are reluctant to become a formal condominium & Organisational structure \\
\hline 4 & Municipality could give more support to condominiums & Context-institutions and policies \\
\hline 5 & Overlapping roles and conflicts with neighbourhood associations & Context-institutions and policies \\
\hline 6 & Bilateral and informal agreements between co-owners to use common areas & Norms \\
\hline 7 & Difficulties in organising big condominiums & Organisational structure \\
\hline \multicolumn{3}{|c|}{ Sociocultural dimension of condominium management } \\
\hline 1 & Bad habits and negative attitudes among residents & Culture and knowledge \\
\hline 2 & Individualism about cooperating and participating in collective initiatives & Action capacity \\
\hline 3 & Distrust in the administrative committee & Action capacity \\
\hline 4 & $\begin{array}{l}\text { Conflicts between residents, especially between ground floor and upper } \\
\text { floor residents }\end{array}$ & Culture and knowledge \\
\hline 5 & Lack of knowledge about duties and rights regarding co-ownership & $\begin{array}{l}\text { Culture and knowledge } \\
\text { Norms }\end{array}$ \\
\hline
\end{tabular}

An important element during the discussion was the knowledge exchanged between participants. A difference in the knowledge and expertise was noted between those who have worked or been in touch with the municipal PSAT and those who have only been informed through private profit entities. Leaders that worked closely with the municipality were better informed about the intervention in the condominium, the subsidy process and the co-property law. At some points in the conversation, they 
started to explain and give advice to less experienced leaders. They also appreciated the opportunity of the group interview to meet each other and hear the experience of other leaders and condominiums.

The leaders recognised that they were now better prepared to undertake a new project and had more tools to negotiate with assistance entities. As previously noted, the fact of being a formal condominium had a positive impact on internal organisation and most were planning to apply for another subsidy. They pointed out that now, as a condominium, they have more visibility and ability to ask for support in the municipality. They emphasised that now 'we are not NN [unknown] in the municipality anymore, so it gives you the right to ask more things and the municipality gives you these things' (Resident B, group interview, January 2016). Some of the benefits that they have received are trees, green areas, alarms in the apartments and garbage receptacles. Although the new status of condominiums has opened new relationships with the municipality, it has not created financial independence as an organisation and it does not necessarily mean the creation of social capital. The role of the municipality was also noted in the conversation, especially regarding the need for more interventions inside the condominiums, and more informative meetings with the residents.

\section{Discussion}

\subsection{Interrelations between Management Dimensions: Identification of Main Triggers}

There are three main topics in which the visions of the residents and stakeholders were conveyed: First, the general and critical physical deterioration of condominiums, especially affecting the common property areas and their associated architectural problems; second, the individualism among neighbours preventing collective actions; and third, the lack of knowledge about the duties and rights derived from co-ownership. Other relevant topics were also recognised, and slight differences in the perception of the same problems were identified. For instance, in the case of the organisational dimension and financial resources, the external vision pointed to the limited financial capacity, while the residents noted an unwillingness or reluctance to pay due to distrust in their leaders, as another variable. Another example is the technical dimension and the physical condition of the condominiums. Extensions and appropriations were identified as equally problematic by external stakeholders, but residents emphasised the appropriations of common ground as the most divisive issue.

Although the dimensions can be understood independently, interviewees noted several problems with origins or consequences closely related to other dimensions. It is, therefore, possible to identify some interdependencies among organisational, technical and sociocultural aspects of the management problem. Within these relations, we distinguish triggers and the consequences these have on a different management aspect.

In this regard, the lack of awareness and education about maintenance, as well as bad habits among neighbourhoods, were identified as triggers for the general deterioration of common areas, the creation of rubbish areas inside condominiums and difficulties eradicating plagues. Similarly, a lack of knowledge about duties and rights, along with individualistic actions, are reflected in neglected maintenance in common areas, the illegal appropriation of the ground floor, or bilateral agreements not approved by the whole condominium. Another important sociocultural trigger is the generalised distrust in leaders and institutions which endanger the organisational capacity. While distrust in the administrative committee triggers reluctance to pay monthly fees for maintenance, the general distrust in institutions hinders the official formalisation of the condominium. A third important sociocultural trigger was related to cultural ways of living, which have an impact on the physical condition of the condominium. Families are used to transform their houses in order to give shelter to their extended family (allegamiento). This situation, combined with limited financial and human resources, results in DIY solutions. These are often precarious constructions, built without professional advice, driven by urgent family needs. 
The construction of low quality and informal extensions in the common property has an impact on the action capacity of residents by triggering conflicts between neighbours. This is especially true when these constructions threaten the free enjoyment of common areas. The initial low-quality construction standards and design shortcomings in condominiums have negative consequences on the internal organisation and the mental wellbeing of their residents. This is an important handicap for maintenance, generating a vicious circle between initial poor design and construction that affect the action capacity of residents, which aggravates the physical deterioration and so forth.

It is important to point out the relevance of contextual factors, mostly identified by external stakeholders, in order to understand problems that go beyond the residents' capacities, and, therefore, cannot be solved within the condominium organisation. One of them is the lack of a clear and comprehensive framework regarding maintenance and administration, which is reflected as a cross-sector lack of clarity regarding responsibilities upon the administration of common domain property, and lack of knowledge about long-term maintenance planning. It is worth mentioning the new insights regarding shortcomings in the implementation of the subsidy programme, noted by the stakeholders, which were validated by residents' perceptions and behaviour during the group interview. Another interesting element was the declared importance of the municipality by the residents and the need for a greater presence in the condominiums.

\subsection{Considerations for Future Actions}

The identification of technical, organisational and sociocultural challenges in condominium management leads to two main considerations to understand management problems in social condominiums and to visualize possible courses of action. The first consideration is the importance of the legalisation process for condominiums in the Real Estate Register to improve general management conditions. In Chile, most, if not all, condominiums' legalisation processes are carried out under the subsidy programme, and are, therefore, associated with an improvement project. Therefore, when a condominium has been legalised, its main organisational elements are settled, the need for urgent improvements has been addressed, and it is more prepared to implement maintenance practices, independently of the level of activity in the organisational structure. Similarly, basic knowledge about condominium law among leaders, and signs of maintenance awareness among some residents make an important difference. It is important to stress, however, that the legalisation of the condominium does not necessarily lead to the creation of social capital or the improvement of maintenance practices in the long-term.

As noted in the interviewees' responses, several important challenges remain unsolved even in condominiums that have been receptors of the subsidy programme. These challenges are the lack of a maintenance plan, the inability to generate a stable maintenance fund, distrust in institutions and leaders, the presence of informal extensions and common ground appropriations, the internal conflicts associated with these appropriations, and the primacy of individualism, which hinders collaboration in maintenance activities. The second consideration is the need of cross-sector support to tackle these challenges.

Firstly, stronger institutional support in the long-term must be implemented for condominium management among low-income homeowners. The subsidy in its current form offers limited support to condominiums. If it is developed under stronger institutional conditions, its implementation would only be one part of a comprehensive policy that assists low-income homeowners throughout their transition to successful ownership. This not only implies clearer regulations and support on maintenance, but also the strengthening of municipalities with regard to their capacity to support and advise low-income homeowners in housing management and conflicts derived from coexistence. Secondly, facilitating access to affordable services for low-income groups. These services could consist of technical assistance for enlargements and refurbishments, condominium administration and legal advice if needed. And last but not least, cross-sector support should aim at validating existent leaderships and supporting them to enhance community cohesion. This would contribute to 
consolidate internal organisations and thus, to improve their action capacity regarding maintenance and administration practices.

\section{Conclusions}

The definition of a comprehensive framework for housing management in the context of low-income homeownership entails an important challenge regarding the role of co-owners as main actors in the process, both individually and collectively. After considering different approaches to understand the concept within organisational management theory, common property management and the asset vulnerability framework, a multidimensional approach was proposed. Housing management for privately-owned affordable condominiums was defined as a multidimensional process with three main interrelated dimensions: technical, organisational and sociocultural. The condominium is understood as a common property resource, collectively managed by co-owners in order to maintain the quality of the built environment. Each dimension is defined by internal elements, related to internal dynamics of condominiums, and contextual elements related to institutional conditions.

The multidimensional approach was used to analyse the management of social condominiums from the perspective of stakeholders, represented by professionals from governmental institutions (SERVIU and MINVU), researchers and assistance entities (municipal, for-profit and non-profit); and by condominium residents, all members of their administrative committees. External stakeholders, such as central government professionals and researchers contributed to the characterisation of contextual elements, while residents and assistance entities provided insights about internal elements and dynamics in condominiums.

Whilst the physical deterioration is the most urgent problem, the importance of sociocultural problems related to knowledge and culture about maintenance, trust and individualism arose during the discussion as important triggers for organisational and technical drawbacks. Elements such as culture and knowledge, and action capacity, play a key role in consolidating organisational elements such as the organisational structure and human and financial resources. They also play a role in technical elements such as physical conditions and maintenance plans. However, the initial low-quality of condominiums, in terms of the facilities and design, is an important handicap for maintenance, fostering a vicious circle starting from an initial poor design that affects the action capacity of residents, which, in turn, aggravates physical deterioration and so forth. Besides the relations between elements, the paper identified specific local dynamics that affect condominium management, such as intergenerational cohabitation (allegamiento) as a reality but also as a source of conflicts, the existence of leadership experience and basic management knowledge in administrative committee members, and the lack of clarity about maintenance responsibilities among institutions and residents.

Based on the identified challenges, the paper concludes with the definition of two main considerations for future actions. Firstly, the relevance of condominium legalisation and its positive impact on overall management conditions. Secondly, the need for cross-sector support to tackle the remaining challenges in order to achieve better management practices in the long-term. Examples of these challenges are the lack of a maintenance plan, the inability to generate a stable maintenance fund, distrust in institutions and leaders, the presence of informal extensions and common ground appropriations and the related conflicts, and the primacy of individualism to cooperate in maintenance activities.

The results provide insights into current management problems in social condominiums located in Santiago. Moreover, the conceptual framework allows for the definition of relevant relations between the management dimensions and their elements. However, the study focused on a particular typology of multi-owned housing in Chile, presenting limitations for generalisation of the results in other groups and settings. Based on these findings, further explorations could use mixed methods to go deeper into the identified management problems, addressing a larger sample to support external validity. 
The rapid deterioration and devaluation of social condominiums in Santiago make it necessary to develop strategies aimed at better housing management practices. Nonetheless, the first step is to understand the nature of the management problems in order to develop suitable solutions. The paper contributed to fill this gap by identifying main management challenges from the direct experience of residents and stakeholders, combining internal and external perceptions of management problems.

Author Contributions: Conceptualization, L.M.V., V.G. and K.v.d.F.; Methodology, L.M.V.; Formal Analysis, L.M.V.; Data Curation, L.M.V.; Writing-Original Draft Preparation, L.M.V.; Writing-Review \& Editing, K.v.d.F. and V.G.; Supervision, V.G. and K.v.d.F.

Funding: This research was funded by National Commission for Scientific and Technological Research of Chile (CONICYT) under Grant PFCHA/Doctorado en el Extranjero, number 72140221.

Conflicts of Interest: The authors declare no conflict of interest.

\section{References}

1. Moser, C.O.N. The asset vulnerability framework: Reassessing urban poverty reduction strategies. World Dev. 1998, 26, 1-19. [CrossRef]

2. Bredenoord, J.; van Lindert, P. Pro-poor housing policies: Rethinking the potential of assisted self-help housing. Habitat Int. 2010, 34, 278-287. [CrossRef]

3. Gough, K.V.; Kellett, P. Housing consolidation and home-based income generation: Evidence from self-help settletments in two Colombian cities. Cities 2001, 18, 235-247. [CrossRef]

4. Acquaye, L. Low-income homeowners and the challenges of home maintenance. Community Dev. 2011, 42, 16-33. [CrossRef]

5. Camargo, A.; Hurtado, A. Vivienda y pobreza: Una relación compleja. Marco conceptual y caracterización de Bogotá. Cuad. Vivienda Urban. 2011, 4, 23.

6. Gruis, V.; Tsenkova, S.; Nieboer, N. Management of Privatised Housing: International Policies E Practice; John Wiley \& Sons: Chichester, UK, 2009.

7. Liias, R. Housing maintenance management: The key-factor when creating healthy environment. Int. J. Environ. Pollut. 2007, 30, 457-470. [CrossRef]

8. Van Zandt, S.; Rohe, W.M. The sustainability of low-income homeownership: The incidence of unexpected costs and needed repairs among low-income home buyers. Hous. Policy Debate 2011, 21, 317-341. [CrossRef]

9. Kessler, G.; di Virgilio, M.M. The new urban poverty: Global, regional and Argentine dynamics during the last two decades. Cepal Rev. 2008, 95, 31-50. [CrossRef]

10. Donoso, R. Governance of condominium affordable housing in Latin America; a network analysis. In Proceedings of the at Home with the Housing Market Conference of ISA RC43 Housing and Built Environment, University of Amsterdam, Amsterdam, The Netherlands, 10-12 July 2013.

11. Yau, Y. Willingness to participate in collective action: The case of multiowned housing management. J. Urban Aff. 2013, 35, 153-171. [CrossRef]

12. Yau, Y. Normas, sentido de comunidad y colectivismo comunal en un contexto de edificios en altura. Rev. INVI 2012, 27, 17-72. [CrossRef]

13. Yau, Y. Perceived efficacies and collectivism in multi-owned housing management. Habitat Int. 2014, 43, 133-141. [CrossRef]

14. Marcuse, P. Homeownership for Low Income Families: Financial Implications. Land Econ. 1972, 48, 134-143. [CrossRef]

15. Derrick, F.; Scott, C.; Kolbre, E. Estonian dwelling owners' association and maintenance policy: The conflict of policy goals and incentives. Eur. Asia Stud. 1999, 51, 1285-1294. [CrossRef]

16. Ducci, M.E. Chile: El lado obscuro de una política de vivienda exitosa. EURE (Santiago) 1997, 23, $99-115$.

17. Rodriguez, A.; Sugranyes, A. El problema de vivienda de los “con techo". In Los Con Techo. Un Desafío Para la Política de Vivienda Social; Rodriguez, A., Sugranyes, A., Eds.; Ediciones SUR: Santiago, Chile, 2005.

18. Brain, I.; Iacobelli, A.; Sabatini, F. Reporte: Calidad y Valor de la Vivienda Social: Un problema de localización y Barrio; ProUrbana. Centro de Políticas Públicas UC: Santiago, Chile, 2005.

19. Brain, I.; Mora, P.; Rasse, A.; Sabatini, F. Report on Social Housing Chile; ProUrbana. Centro de Políticas Públicas UC: Santiago, Chile, 2009. 
20. Gilbert, A. Helping the poor through housing subsidies: Lessons from Chile, Colombia and South Africa. Habitat Int. 2004, 28, 13-40. [CrossRef]

21. MINVU. Vivienda Social en Copropiedad. Memoria de Tipologias de Condominios Sociales; Ministerio de Vivienda y Urbanismo: Santiago, Chile, 2014.

22. Oezler, S.I. The Concertacion and Homelessness in Chile Market-based Housing Policies and Limited Popular Participation. Lat. Am. Perspect. 2012, 39, 53-70. [CrossRef]

23. Rodríguez, A.; Sugranyes, A. Los Con Techo: Un Desafío Para la Política de Vivienda Social; Ediciones SUR: Santiago, Chile, 2005; 265p.

24. Rubio Vollert, R. Lecciones de la política de vivienda en Chile. Bitacora 2006, 10, 197-206.

25. MINVU. Vivienda Social en Copropiedad. Catastro Nacional de Condominios Sociales; Ministerio de Vivienda y Urbanismo: Santiago, Chile, 2014.

26. MINVU. Ley 20.741 Modifica la ley $N^{\circ}$ 19.537, Sobre Copropiedad Inmobiliaria Para Facilitar la Administracion de Copropiedades y la Presentación de Proyectos de Mejoramiento o Ampliacion de Condominios de Viviendas Sociales; Ministerio de Vivienda y Urbanismo: Santiago, Chile, 2014.

27. Priemus, H.; Dieleman, F.; Clapham, D. Current developments in social housing management. Neth. J. Hous. Built Environ. 1999, 14, 211-223. [CrossRef]

28. Gruis, V.; Nieboer, N.; Thomas, A. Strategic asset management in the social rented sector: Approaches of Dutch and English housing associations. Urban Stud. 2004, 41, 1229-1248. [CrossRef]

29. Straub, A. Housing management and maintenance practise of Dutch housing associations. In Proceedings of the ENHR 2004 Conference, Cambridge, UK, 2-6 July 2004.

30. Walker, R.M. The changing management of social housing: The impact of externalisation and managerialisation. Hous. Stud. 2000, 15, 281-299. [CrossRef]

31. Straub, A. Maintenance and Repair. In International Encyclopedia of Housing and Home; Smith, S.J., Ed.; Elsevier: San Diego, CA, USA, 2012; pp. 186-194.

32. Ariff, N.R.M.; Davies, H. Multi-owner low-cost housing management in Malaysia: Effects of owner-occupant characteristics and occupancy rates. Int. J. Hous. Mark. Anal. 2011, 4, 268-289. [CrossRef]

33. Donoso, R.E.; Elsinga, M. Management of low-income condominiums in Bogotá and Quito: The balance between property law and self-organisation. Int. J. Hous. Policy 2018, 18, 312-334. [CrossRef]

34. Reid, S. Exploring social interactions and sense of community in multi-owned properties. Int. J. Hous. Mark. Anal. 2015, 8, 436-450. [CrossRef]

35. Olson, M., Jr. The Logic of Collective Action: Public Goods and the Theory of Groups, 9th ed.; Harvard economic studies; Harvard University Press: Cambridge, MA, USA, 1982; Volume 124.

36. Ostrom, E. Governing the Commons. The Evolution of Institutions for Collective Action; Cambridge University Press: Cambridge, UK, 1990.

37. Chen, S.C.Y.; Webster, C.J. Homeowners Associations, Collective Action and the Costs of Private Governance. Hous. Stud. 2005, 20, 205-220. [CrossRef]

38. Chu, F.N.; Chang, C.O.; Sing, T.F. Collective Action Dilemmas in Condominium Management. Urban Stud. 2013, 50, 128-147. [CrossRef]

39. Pérez, A. Copropiedad Inmobiliaria. In Precariedad y Organización: El Caso del Condominio Quillayes de la Comuna de La Florida, in Instituto de Estudios Urbanos y Territoriales; Pontificia Universidad Católica de Chile: Santiago, Chile, 2009; p. 183.

40. Gao, L.W.; Ho, D.C.W. Explaining the outcomes of multi-owned housing management: A collective action perspective. Habitat Int. 2016, 57, 233-241. [CrossRef]

41. Ostrom, E. Background on the Institutional Analysis and Development Framework. Policy Stud. J. 2011, 39, 7-27. [CrossRef]

42. Cavalheiro, D.D.; Abiko, A. Evaluating slum (favela) resettlements: The case of the Serra do Mar Project, Sao Paulo, Brazil. Habitat Int. 2015, 49, 340-348. [CrossRef]

43. Teles, R.; González, M.S. Social housing enlargement-Case of study: Ivoti-Brazil. Rev. Ing. Constr. 2013, 28, 237-250. [CrossRef]

44. Marquez, F. De lo Material y lo Simbólico en la Vivienda Social. In Los Con Techo: Un Desafío Para la Política de Vivienda Social; Rodríguez, A., Sugranyes, A., Eds.; Ediciones SUR: Santiago, Chile, 2005. 
45. Gao, W.; Chen, G.-Z. Does owner heterogeneity matter in the management of multi-owned housing? Habitat Int. 2016, 53, 106-114. [CrossRef]

46. Smithson, J. Using and analysing focus groups: Limitations and possibilities. Int. J. Soc. Res. Methodol. 2000, 3, 103-119. [CrossRef] 